\title{
Vegetation NDVI Change and Its Relationship with Climate Change and Human Activities in Yulin, Shaanxi Province of China
}

\author{
Tao Wang1,2,3 \\ ${ }^{1}$ College of Geomatics, Xi'an University of Science and Technology, Xi'an, China \\ ${ }^{2}$ College of Urban and Environmental Science, Northwest University, Xi'an, China \\ ${ }^{3}$ State Key Laboratory of Soil Erosion and Dryland Farming on the Loess Plateau, Institute of Water and Soil Conservation, \\ Chinese Academy of Sciences and Ministry of Water Resources, Yangling, China \\ Email: wht432@163.com
}

How to cite this paper: Wang, T. (2016) Vegetation NDVI Change and Its Relationship with Climate Change and Human Activities in Yulin, Shaanxi Province of China. Journal of Geoscience and Environment Protection, 4, 28-40.

http://dx.doi.org/10.4236/gep.2016.410002

Received: September 8, 2016

Accepted: October 10, 2016

Published: October 13, 2016

Copyright $\odot 2016$ by author and Scientific Research Publishing Inc. This work is licensed under the Creative Commons Attribution International License (CC BY 4.0).

http://creativecommons.org/licenses/by/4.0/

(c) (i) Open Access

\begin{abstract}
Yulin is a typical ecological fragile area in China, and its vegetation ecosystem is so fragile that could be vulnerable to climate change and human activities. Spatial and temporal change of vegetation Normalized Difference Vegetation Index (NDVI) and its relationship with climate change and human activities were analyzed based on MODIS NDVI data from 2000 to 2015, as well as annual temperature and precipitation data from 2000 to 2014, and linear trend analysis, correlation and buffer analysis were used. Result showed: 1) NDVI value was small and vegetation cover was low, but NDVI had a linear growth rate of 0.0096/annum from 2000 to 2015 in Yulin area. The area of growth trend accounted for $97.06 \%$ of the total area, while the area with decreased rate was small, which mainly had correlation with human activities, and was distributed in the southwest mountain area, urban neighborhood, and river valley in the middle and east of Yulin area. 2) Correlation analysis between NDVI and temperature, precipitation, respectively, reflected that negative correlation was between NDVI and temperature, while positive correlation was between NDVI and precipitation. Furthermore, the role of precipitation was higher than that of temperature in the process of interaction between NDVI and temperature, precipitation. 3) NDVI change process in the range of human activities indicated that the intensity of human activities in buffer_city area was higher than that in buffer_county area. Buffer_city area was divided into within $5 \mathrm{~km}$ area with dramatic impact by human activities, and from $5 \mathrm{~km}$ to $9 \mathrm{~km}$ area with less impact by human activities, and outside $9 \mathrm{~km}$ area with mini-affected by human activities.
\end{abstract}

\section{Keywords}

NDVI, Temperature, Precipitation, Human Activities, Yulin 


\section{Introduction}

Vegetation is an important part of terrestrial ecosystems; it is also the link among climate, hydrology, and soil material and energy cycle [1]-[3]. The industrial revolution, global warming occurred, which also showed a significant increase process of land temperature in China [4]. At the global and regional climate change process, vegetation plays an important role in reflecting and characterizing terrestrial ecosystem change, hydrological cycle, soil ecosystems and regional human activities [5]-[7].

This study on vegetation NDVI change and its relationship with climate change and human activities includes 3 aspects. The first is to analyze different spatial and temporal vegetation cover change in global and regional scale based on GIMMS NDVI, SPOT VGT NDVI, MODIS NDVI and Landsat NDVI data [8]-[11]. The second is to analyze the effect of climate change on vegetation based on the correlation coefficient and linear change trend method [12]-[14]. The third is to analyze the relationship between vegetation and human activities, which has positive and negative effects on vegetation change. For example, returning farmland to forest and grassland project and ecological protection and construction project play a positive role [15] [16], while other human activities mainly play a negative role, leading to low and deteriorated vegetation cover [17] [18]. On the aspect of relationship between vegetation and climate change, human activities, respectively, the conclusions focus on vegetation in large scale under control of climate change, while small scale under control of human activities [19] [20].

Yulin is located in the agro-pastoral transitional zone, and is the typical ecological fragile area in China. For the effect of East Asia monsoon, precipitation has a greater uncertainty in the area [21] [22]. The study on vegetation NDVI change and its relationship with climate change and human activities contributes to assessment of the effect of ecological protection policy, and of the different role of climate change and human activities on the process of vegetation change.

\section{Methods}

\subsection{Study Area}

Yulin is located in northern Shaanxi province of China, and is over the transitional zone between Loess Plateau and the $\mathrm{Mu}$ Us Sandilands, the geographical coordinate between $107^{\circ} 15^{\prime} 47^{\prime \prime}-111^{\circ} 14^{\prime} 44^{\prime \prime E}$ and $36^{\circ} 49^{\prime} 07^{\prime \prime}$ - 39 $34^{\prime} 47^{\prime \prime} \mathrm{N}$ (Figure 1). Yulin experiences semi-arid temperate continental monsoon climate, dry and little precipitation in spring and winter, while hot and more rain in summer and autumn, and the annual average temperature is $9.6^{\circ} \mathrm{C}$, annual average precipitation is $440 \mathrm{~mm}$. The annual average temperature and precipitation decreases from southeast to northwest [23]. Landscape in Yulin can be divided into 2 types: one is the Mu Us Sandilands in the northern region with low vegetation cover, the other is the loess hilly and gully in the southern region, where vegetation change is influenced by human activities and mostly natural vegetation reclaimed to farmland, but after 1999, vegetation cover in the region has improved due to returning farmland to forest and grassland. Yulin area includes the Yellow river basin, and the main river includes Wuding river, Kuye river and Tuwei river. 


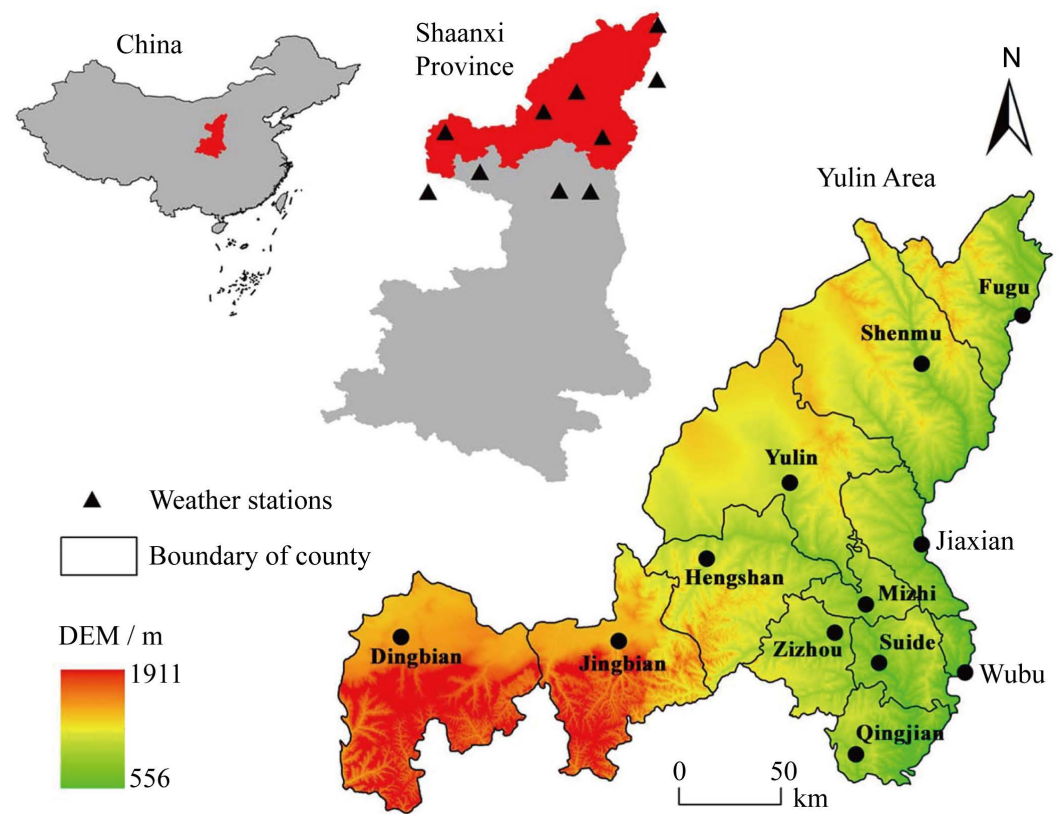

Figure 1. Study area and distribution of weather stations.

\subsection{Data}

The data included: 1) $250 \mathrm{~m}$ resolution and $16 \mathrm{~d}$ synthetic 13Q1-level 3 MODIS NDVI products were downloaded from http://ladsweb.nascom.nasa.gov. Modis Reprojection Tool (MRT) was used for decoding, stitching, reprojection and format conversion of the MODIS data, and getting monthly average MODIS NDVI data of Yulin from 2000 to 2015 with Maximum Value Composition (MVC) method. 2) Yearly temperature and precipitation data from 2000 to 2014 of 10 weather stations located in Yulin and its neighborhood (Figure 1), were downloaded from Geospatial Data Cloud, Computer Network Information Center, Chinese Academy of Sciences (http://data.cma.cn). Inverse Distance Weighted (IDW) method was used to get spatial distribution data of annual average temperature and annual precipitation from 2000 to 2014. 3) Administrative boundaries of Yulin in vector format.

\subsection{Methods}

Linear trend method can be used to analyze spatial and temporal vegetation cover change trend, it is calculated as [24]:

$$
\begin{gathered}
Y=\mathrm{a} X+\mathrm{b} \\
a=\left(\sum_{i=1}^{n} x_{i} y_{i}-n \overline{x y}\right) /\left(\sum_{i=1}^{n} x_{i}^{2}-n \bar{x}^{2}\right)
\end{gathered}
$$

where $Y$ and $y$ are vegetation NDVI spatial distribution data or value of study area from 2000 to 2015; $X$ and $x$ are years from 2000 to 2015; $a$ is a coefficient; $b$ is a constant; $\bar{X}$ and $\bar{y}$ are the average value of $X$ and $Y$, respectively. Positive and negative of $a$ value reflect the increase and decrease of linear trend of vegetation NDVI, respectively. 
Correlation coefficient is mainly used to analyze the relationship between 2 independent variables, and is calculated as [24]:

$$
r=\left[\sum_{i=1}^{n}\left(x_{i}-\bar{x}\right)\left(y_{i}-\bar{y}\right)\right] /\left(\sqrt{\sum_{i=1}^{n}\left(x_{i}-\bar{x}\right)^{2}} \sqrt{\sum_{i=1}^{n}\left(y_{i}-\bar{y}\right)^{2}}\right)
$$

where $x$ and $y$ are temperature and precipitation from 2000 to 2014, respectively. $r$ value is between $[-1,1]$ and $r=0$ indicates no correlation between 2 variables, while the stronger negative correlation when $r$ close to -1 , and stronger positive correlation when $r$ close to 1 . Inquired critical correlation coefficient table, when $\alpha=0.05$, the critical value is 0.5139 , that is results significant when $|r|>0.5139$, otherwise not significant.

Vegetation is influenced by temperature and precipitation, so partial correlation coefficient is a good index to analyze the relationship among them. Suppose the correlation coefficient between vegetation NDVI and temperature, precipitation, and between temperature and precipitation are expressed as $r_{12}, r_{13}, r_{23}$, so the partial correlation coefficients are calculated as:

$$
\begin{aligned}
& r_{12 \cdot 3}=\left(r_{12}-r_{13} \times r_{23}\right) / \sqrt{\left(1-r_{13}^{2}\right) \times\left(1-r_{23}^{2}\right)} \\
& r_{13 \cdot 2}=\left(r_{13}-r_{12} \times r_{23}\right) / \sqrt{\left(1-r_{12}^{2}\right) \times\left(1-r_{23}^{2}\right)}
\end{aligned}
$$

where, $r_{12.3}, r_{13.2}$ are represent partial correlation coefficient of vegetation NDVI and temperature, precipitation, respectively. Significant test of the partial correlation coefficients is used t-test, and is calculated as:

$$
\begin{aligned}
& t_{12 \cdot 3}=r_{12 \cdot 3} \times \sqrt{n-m-1} / \sqrt{1-r_{12 \cdot 3}^{2}} \\
& t_{13 \cdot 2}=\times r_{13 \cdot 2} \sqrt{n-m-1} / \sqrt{1-r_{13 \cdot 2}^{2}}
\end{aligned}
$$

where, $n$ is 15 of the number of samples; $m$ is 2 of the number of independent variables. Check $t$ distribution table, when $\alpha=0.05$, the critical value was 2.179 , that was $|t|>$ 2.179 , significant of partial correlation coefficient, whereas not significant.

\section{Results}

\subsection{Dynamic Changes of Vegetation NDVI}

NDVI value in Yulin was between 0.3001 and 0.4913 . Between 2000 and 2015, the value of NDVI had an increasing trend which can be divided into 5 stages, 2000-2002, 2002-2006, 2006-2009, 2009-2013 and 2013-2015, respectively. Of which the first four stages showed an increasing or relatively stable trend (2000-2006), but the last stage showed a decreasing process. Overall, vegetation NDVI in Yulin showed a linear growth trend, and the growth rate was 0.0096/annum, which passed the 0.001 significant $\mathrm{t}$-test and reflected that regional vegetation would be increase in future. Although the overall showed a linear growth trend, while the decreasing trend after 2013 would indicate vegetation degradation (Figure 2). 
Linear change rate of NDVI in Yulin between 2000 and 2015 was mainly increasing area in the whole, while decreasing area was small. As showed in Figure 3, linear growth area accounted for $97.06 \%$ of the total area, while only $2.94 \%$ of decreasing area accounted. In conjunction with Figure 1 of DEM distribution, the decreasing area mainly distributed in 3 regions, the first was high altitude area, such as the south and southeast of Dingbian county. The second was urban neighborhood area and the third was distributed along the river valley, which was Kuye river, Yuxi river and Wuding river from north to south. The reason of vegetation degradation for the first region may be related to climate change, while the latter two regions by human activities obviously, which included urban expansion and energy chemical base construction in northern Shaanxi.

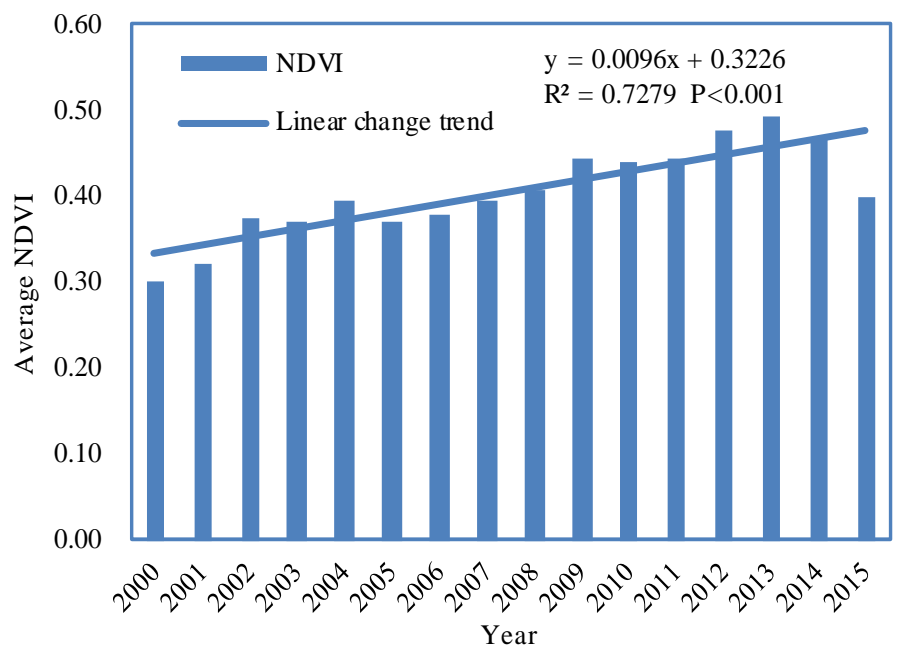

Figure 2. Variation of NDVI trend in Yulin between 2000 and 2015.

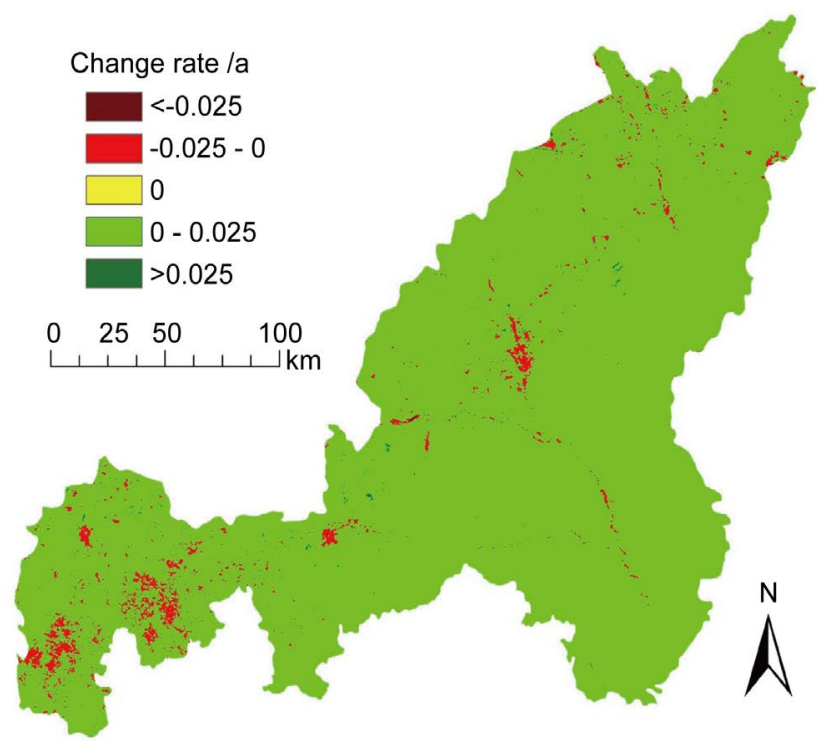

Figure 3. Linear change in the rate of NDVI in Yulin between 2000 and 2015. 


\subsection{Relationship between Vegetation NDVI and Climate Change}

The correlation coefficient, partial correlation coefficient and its t-test results mainly reflected negative correlation between vegetation NDVI and temperature (Figure 4(a), Figure 4(c), Figure 4(e)). In the spatial distribution of correlation coefficient, negative
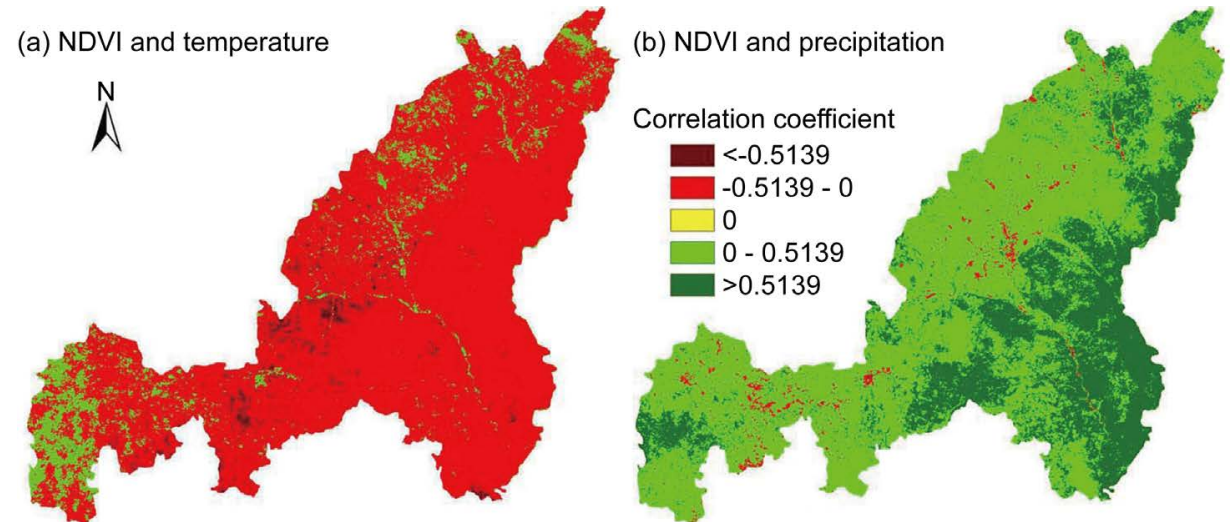

(c) NDVI and temperature

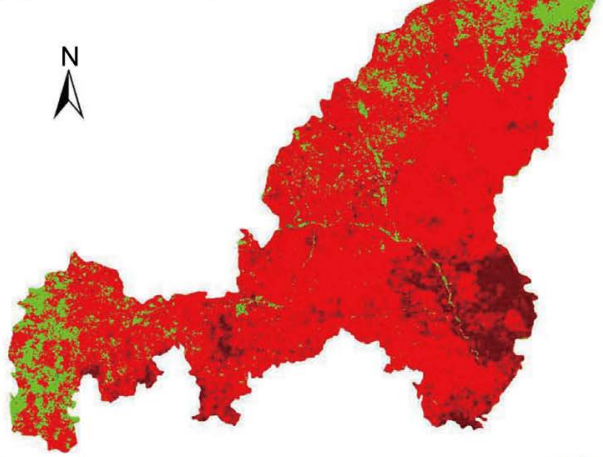

(e) NDVI and temperature

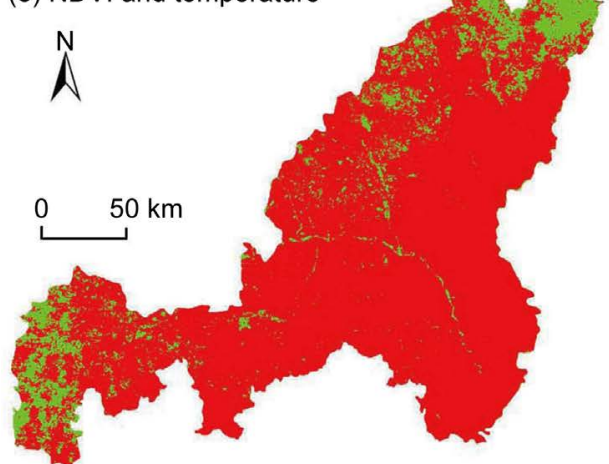

(d) NDVI and precipitation

Partial correlation coefficient

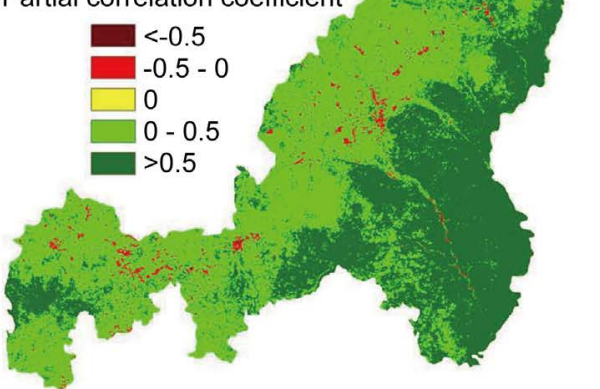

(f) NDVI and precipitation

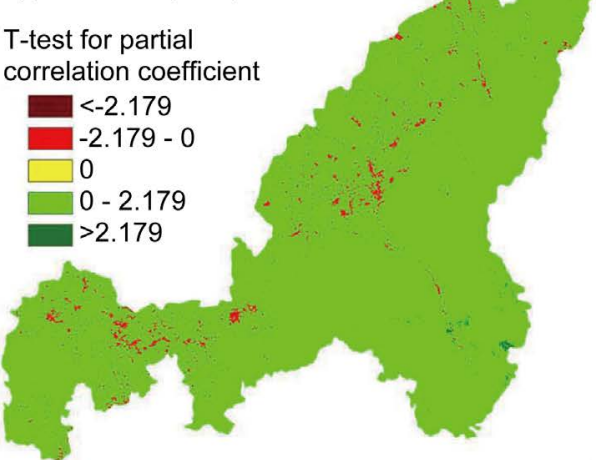

Figure 4. Correlation coefficient ( $a, b)$, partial correlation coefficient (c, d), and its t-test results $(e, f)$ between vegetation NDVI and temperature, precipitation. Correlation coefficient of $\mathrm{a}$ and $\mathrm{b}$ was divided into 5 types with the critical value of 0.5139 when $\alpha=0.05$, where $<-0.5139$ and $>0.5139$ represented a significant correlation, and 0 indicated no correlation, the others was not significant. Partial correlation coefficient of $\mathrm{c}$ and $\mathrm{d}$ was divided into 5 types according to 0.5 . T-test results of e and $\mathrm{f}$ was also divided into 5 types with the critical value of 2.179 when $\alpha=0.05$, where $<-2.179$ and $>2.179$ represented significant partial correlation, and 0 indicated no partial correlation, the others were no significant. 
correlation area accounted for $90.3 \%$ with wide distribution, and significant correlation area only accounted for $2.9 \%$ which mainly distributed in the middle and west area, northwest area of Jingbian and Hengshan County internally. Positive correlation only account for $9.7 \%$ which mainly distributed in the west area of Dingbian County, the other area located in the middle and north area along Wuding river, Yuxi river and Kuye river (Figure 4(a)).

In the spatial distribution of partial correlation coefficient, negative partial correlation coefficient accounted for $87.0 \%$, where $<-0.5$ region accounted for $11.5 \%$ which mainly distributed in the southeast of loess hilly region of Mizhi, Jiaxian, Suide, Wupu county, and scattered distribution in the middle area of Jingbian county and the southeast edge of Dingbian county. Positive partial correlation coefficient only accounted for 13.0\%, which mainly distributed in the west and northern edge area (Figure $4(\mathrm{c})$ ).

The spatial distribution of t-test results was similar to partial correlation coefficient. Although negative partial correlation was the main relationship between vegetation NDVI and temperature, but significant negative partial correlation area only accounted for $0.01 \%$, while positive correlation area also approximate to 0 (Figure $4(\mathrm{e})$ ).

Negative correlation between vegetation NDVI and temperature was not significant which reflected the possibility of vegetation NDVI change could not be identified in future. In addition, by comparing the area of negative correlation and partial correlation coefficient, negative partial correlation area decreased by $3.3 \%$. So the role of precipitation in the interaction process between vegetation NDVI and temperature was $3.3 \%$.

Contrary to the correlation between vegetation NDVI and temperature, the correlation between vegetation NDVI and precipitation was mainly positive which was reflected by correlation and partial correlation coefficient and its t-test results. In the spatial distribution of correlation coefficient, positive correlation area accounted for $97.0 \%$, where significant positive correlation accounted for $33.6 \%$ which mainly distributed in the southeast area of Mizhi, Jiaxian, Suide, Wupu county and the middle area of southeast of Yuyang district and south of Hengshan county. In addition, large area was also distributed in the north of Fugu, Shenmu county, and the middle of Dingbian county. Negative correlation only accounted for $3 \%$ which mainly distributed in the urban neighborhood of Dingbian, Jingbian county and Yulin city (Figure 4(b)).

In the spatial distribution of partial correlation coefficient, positive partial correlation accounted for $97.1 \%$, where $>0.5$ area accounted for $43.7 \%$, which was similar to positive correlation coefficient (Figure 4(d)). T-test results showed that no significant partial correlation was the main distribution while positive partial correlation only accounted for $0.2 \%$ (Figure $4(\mathrm{f})$ ). Comparing the correlation and partial correlation coefficient, the role of temperature in the interaction process between vegetation NDVI and precipitation was only $0.1 \%$, below $3.3 \%$ of the role of precipitation.

\subsection{Relationship between Vegetation NDVI and Human Activities}

Urban expansion in nowadays is one of the largest effect on vegetation change of hu- 
man activities. Take city and county administration as buffer center and $15 \mathrm{~km}$ and 10 $\mathrm{km}$ as radius, the area of human activities was extracted by buffer analysis tool (Figure $5)$.

On the basis of buffer area, spatial and temporal average NDVI value and its linear change rate in Yulin from 2000 to 2015 were extracted (Figure 6).

Average NDVI and linear change rate in buffer_city area were lower than buffer county area. Average NDVI in buffer_county area was distribute in the range of 0.35 0.45 , and linear change rate was positive in the range of $0.002-0.012$, while in the range of $0.20-0.40$ of average NDVI and of $-0.006-0.008$ of linear change rate in buffer_city area. The result showed the effect of human activities in city area was higher than in county area (Figure 6).

In Figure 6(a), the change process of average NDVI value in buffer_city and buffer_ county area was divided into 2 ranges of $<3 \mathrm{~km}$ and $>3 \mathrm{~km}$. The former range in buffer_city and buffer_county area showed a linear growth process, and the linear growth rate was 0.0764/annum and 0.0456/annum, respectively. The latter range showed a linear reduction process, and the linear reduction rate was 0.0044/annum and 0.0002/ annum, respectively. The change process of average NDVI in buffer_city and buffer county indicated that human activites in buffer_city was higher than in buffer_county leading to a great change in buffer_city, while a little change in buffer_county.

The change process of linear changerate of NDVI in buffer_city and buffer_county was different. Change process in buffer_city was divided into 2 ranges of $<9 \mathrm{~km}$ and $>9$ $\mathrm{km}$, the former range also was divided into 2 ranges of $<5 \mathrm{~km}$ and $5-9 \mathrm{~km}$. In the
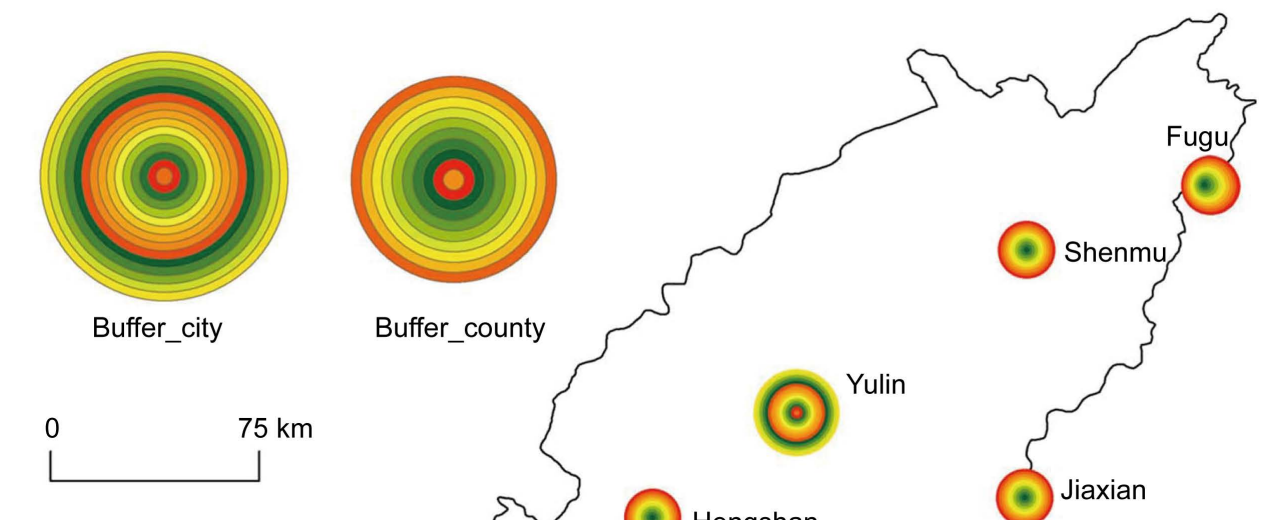

Buffer_county

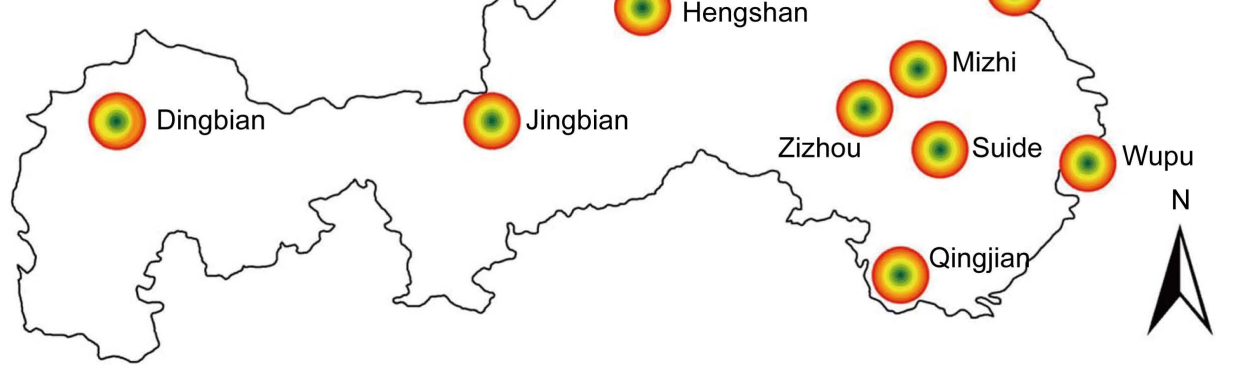

Figure 5. The range of human activities. Buffer_city was take the city administration as center and $15 \mathrm{~km}$ as radius, with $1 \mathrm{~km}$ as buffer distance, while buffer_county was take the county administration as center and $10 \mathrm{~km}$ as radius, with $1 \mathrm{~km}$ as buffer distance. 


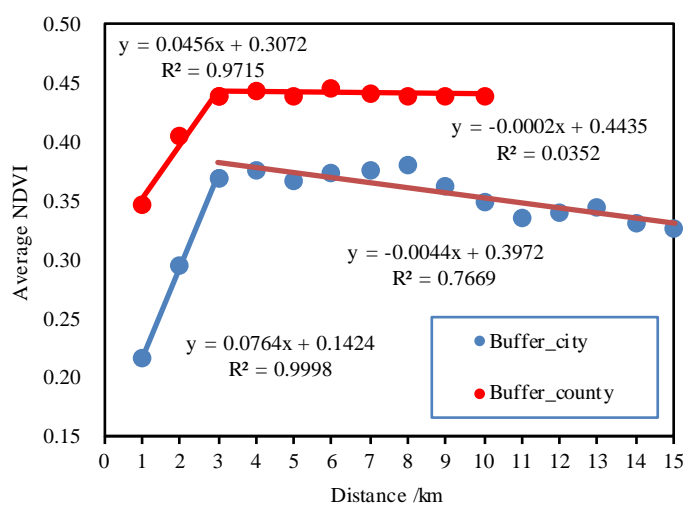

(a)

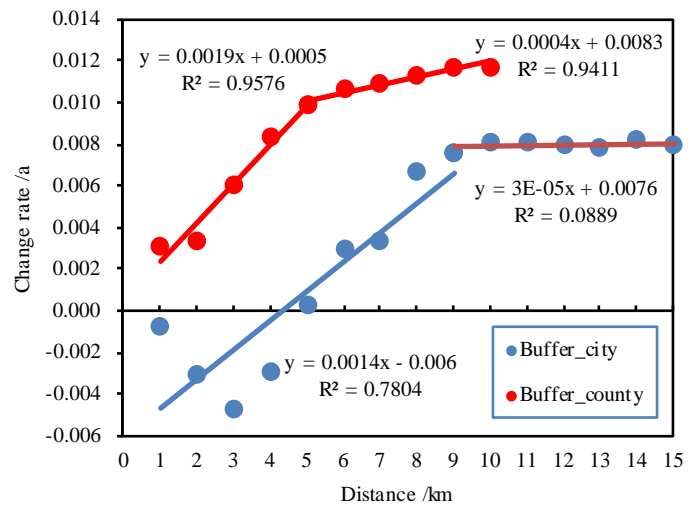

(b)
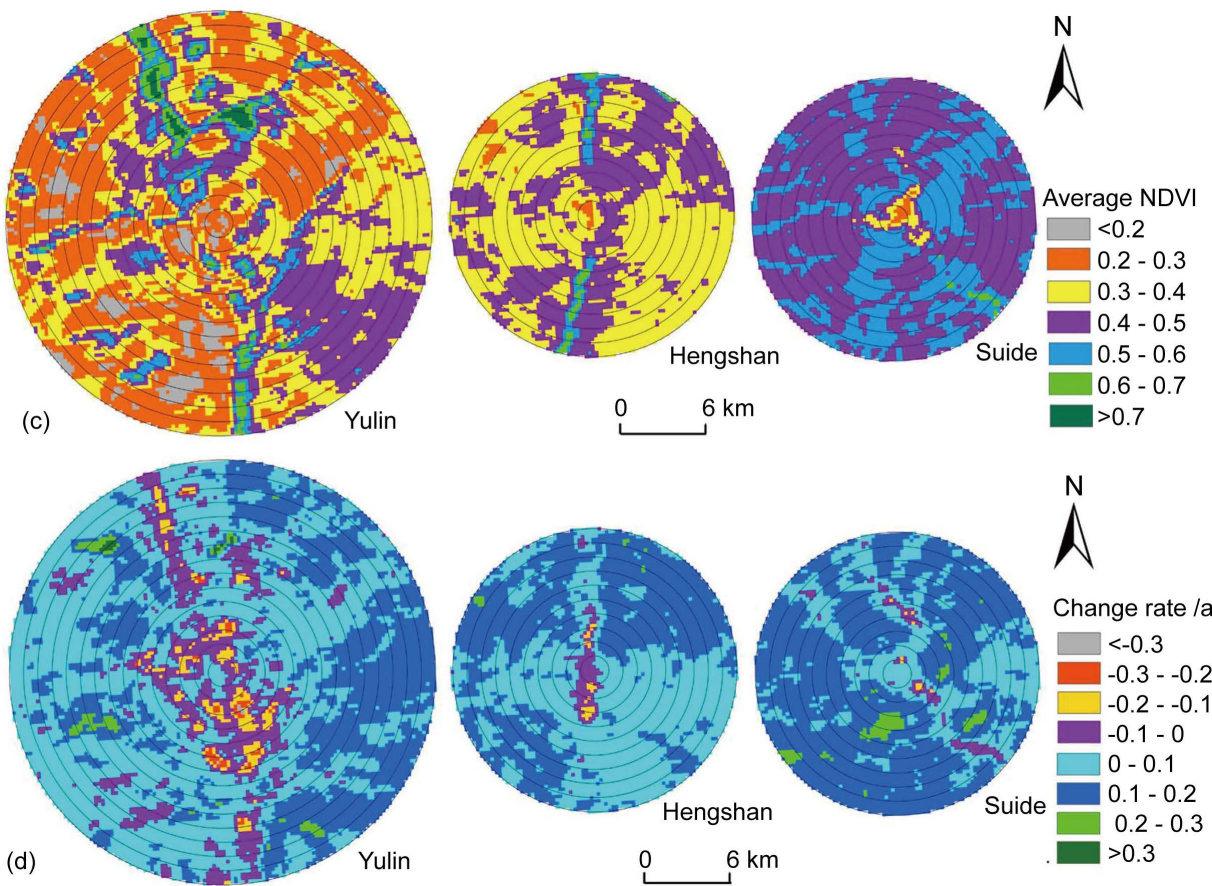

Figure 6. Vegetation NDVI change in the range of human activities. The figures (a) and (b) were the change process of average vegetation NDVI and linear change rate with the distance to city and county administration center, respectively. The figures (c) and (d) were spatial distribution of the change process of average vegetation NDVI and linear change rate in the range of buffer city and county. 
range of $<5 \mathrm{~km}$, linear change rate was negative which reflected that vegetation had been degradation in the past 16 years by the effect of urban expansion. In the range of 5 - $9 \mathrm{~km}$, linear change rate turned into positive which reflected vegetation natural growth process was not affected by human activities, while with the increase of distance, linear change rate was increase gradually and the effect of human activities was decrease gradually. In the latter range of $>9 \mathrm{~km}$, linear change rate was stabilized and the vegetation change was natural state unaffected by human activities (Figure 6(b)).

The change process of linear change rate in buffer_county was divided into 2 ranges of $<5 \mathrm{~km}$ and $>5 \mathrm{~km}$. The former range increased rapidly with growth rate of $0.0019 / \mathrm{a}$, while the latter range increased moderately with the growth rate of $0.0004 / \mathrm{a}$. Which all reflected that vegetation in the range of $<5 \mathrm{~km}$ was affected by human activities, and the closer to administration center, the impact greater, otherwise, the impact smaller. Contrary to buffer_city area, linear change rate in buffer_county was positive which indicated that the smaller impact of human activities on vegetation in buffer_county to change the natural process of vegetation (Figure 6(b)).

Spatial distribution of average NDVI and linear change rate in Yulin city, Hengshan and Suide county were shown in Figure 6(c) and Figure 6(d). Yulin city landform is flat and most of the area is sand land, which located in the northwest and loess plateau in the southeast of Hengshan county and Suide county. For the different landform in the 3 administration center, the average NDVI and linear change rate were showed different spatial distribution. For example, Yulin city was similar to Hengshan county, and the average NDVI value distributed in the range of $0.2-0.5$, whereas NDVI value of Yulin city and Hengshan county was distributed in the range of $0.2-0.4$ and $0.3-0.5$, respectively, while of Suide county was distributed in the range of $0.4-0.6$, only administration center neighborhood was distributed in the range of $0.2-0.3$, which indicated that the large difference spatial distribution in buffer_city and the disturbance of human activities on vegetation was present a discontinuous distribution state, while small difference was distributed in buffer_county area (Figure 6(c)). In the spatial distribution of linear change rate, linear change rate in Yulin city, Hengshan and Suide county was positive and distributed in the range of $0-0.2 /$ a. The negative value was mainly distributed in the administration center of Yulin city and on the both sides of Yuxi river, in the heart area of Hengshan county and the tributary valleys of Wuding river from south to north (Figure 6(d)).

\section{Conclusions}

NDVI value was small and vegetation cover level was low, but vegetation NDVI had a linear growth rate of 0.0096/annum from 2000 to 2015 in Yulin area. The area of growth trend accounted for $97.06 \%$ of the total area, while the area with decreased rate was small, which mainly had correlation with human activities, and was distributed in the southwest mountain area, urban neighborhood, and river valley in the middle and east of Yulin area.

Correlation analysis between vegetation NDVI and temperature, precipitation, re- 
spectively, reflected that negative correlation was between vegetation NDVI and temperature, while positive correlation was between vegetation NDVI and precipitation. Furthermore, the role of precipitation was higher than that of temperature in the process of interaction between vegetation NDVI and climate change.

Vegetation NDVI change process in the range of human activities indicated that the intensity of human activities in buffer_city aera was higher than that in buffer_county area. Buffer_city area was divided into less than $5 \mathrm{~km}$ area with dramatic impact by human activities, as well as from $5 \mathrm{~km}$ to $9 \mathrm{~km}$ area with reducing impact by human activities, and $9 \mathrm{~km}$ outside area with unaffected by human activities.

Yulin region is the transitional zone between Mu Us Sandland and Loess Plateau hilly topography. The vegetation was changed by the climate warming and the vegetation cover would be reduced. If the precipitation increases in the future, the ecological environment would be improved gradually, otherwise it will tend to deteriorate. Precipitation conditions play an important role in the process and have been confirmed in this paper. In the past 16 years, vegetation in the study area has been improved by the implementation of grain for green project, while the reduction area of vegetation was distributed around urban area due to the impact of human activities. Vegetation change in the future in study area would be affected by climate change in passive and by constraints and change human activities on vegetation to improve vegetation cover levels and ecological environment.

\section{Acknowledgements}

This work was supported by the National Natural Science Foundation of China (41271103, 41501571), Scientific Research Program Funded by Shaanxi Provincial Education Department (14JK1479), Natural Science Basic Research Plan in Shaanxi Province of China (2015JQ4110), The Open Foundation of State Key Laboratory of Soil Erosion and Dryland Farming of the Loess Plateau (A314021402-1616).

\section{References}

[1] Walther, G.R., Post, E., Convey, P., Menzel, A., Parmesan, G., Beebee, T.J.C., Fronmentin, J.M., Guldberg, O.H. and Bairlein, F. (2002) Ecological Responses to Recent Climate Change. Nature, 416, 389-395. http://dx.doi.org/10.1038/416389a

[2] Hilker, T., Lyapustin, A.I., Hall, F.G., Myneni, R., Knyazikhin, Y., Wang, Y., Tucker, C.J. and Sellers, P.J. (2015) On the Measurability of Change in Amazon Vegetation from MODIS. Remote Sensing of Environment, 166, 233-242. http://dx.doi.org/10.1016/j.rse.2015.05.020

[3] Ochoa, P.A., Fries, A., Mejía, D., Burneo, J.I., Sinoga, J.D.R. and Cerdá, A. (2016) Effects of Climate, Land Cover and Topography on Soil Erosion Risk in a Semiarid Basin of the Andes. CATENA, 140, 31-42. http://dx.doi.org/10.1016/j.catena.2016.01.011

[4] Gao, X.J., Shi, Y., Zhang, D.F. and Giorgi, F. (2012) Climate Change in China in the 21st Century as Simulated by a High Resolution Regional Climate Model. Chinese Science Bulletin, 57, 1188-1195. http://dx.doi.org/10.1007/s11434-011-4935-8

[5] Stefanov, W.L. and Netzband, M. (2005) Assessment of ASTER Land Cover and MODIS 
NDVI Data at Multiple Scales for Ecological Characterization of an Arid Urban Center. Remote Sensing of Environment, 99, 31-43. http://dx.doi.org/10.1016/j.rse.2005.04.024

[6] Kirkpatrick, J.B., Green, K., Bridle, K.L. and Venn, S.E. (2014) Patterns of Variation in Australian Alpine Soils and Their Relationships to Parent Material, Vegetation Formation, Climate and Topography. CATENA, 121, 186-194. http://dx.doi.org/10.1016/j.catena.2014.05.005

[7] Zhou, D.C., Zhao, S.Q., Zhang, L.X. and Liu, S.G. (2016) Remotely Sensed Assessment of Urbanization Effects on Vegetation Phenology in China's 32 Major Cities. Remote Sensing of Environment, 176, 272-281. http://dx.doi.org/10.1016/j.rse.2016.02.010

[8] Fensholt, R. and Proud, S.R. (2012) Evaluation of Earth Observation Based Global Long Term Vegetation Trends-Comparing GIMMS and MODIS Global NDVI Time Series. Remote Sensing of Environment, 119, 131-147. http://dx.doi.org/10.1016/j.rse.2011.12.015

[9] Yang, Q., Qin, Z.H., Li, W.J. and Xu, B. (2012) Temporal and Spatial Variations of Vegetation Cover in Hulun Buir Grassland of Inner Mongolia, China. Arid Land Research and Management, 26, 328-343. http://dx.doi.org/10.1080/15324982.2012.709215

[10] Boschetti, M., Nutini, F., Brivio, P.A., Bartholomé, E., Stroppiana, D. and Hoscilo, A. (2013) Identification of Environmental Anomaly Hot Spots in West Africa from Time Series of NDVI and Rainfall. ISPRS Journal of Photogrammetry and Remote Sensing, 78, 26-40. http://dx.doi.org/10.1016/j.isprsjprs.2013.01.003

[11] Sangermano, F., Bol, L., Galvis, P., Gullison, R.E., Hardner, J. and Ross, G.S. (2015) Forest Baseline and Deforestation Map of the Dominican Republic through the Analysis of Time Series of MODIS Data. Data in Brief, 4, 363-367. http://dx.doi.org/10.1016/j.dib.2015.06.006

[12] Liu, W.B., Cai, T.J., Ju, C.Y., Fu, G.B., Yao, Y.F. and Cui, X.Q. (2011) Assessing Vegetation Dynamics and Their Relationships with Climatic Variability in Heilongjiang Province, Northeast China. Environmental Earth Sciences, 64, 2013-2024. http://dx.doi.org/10.1007/s12665-011-1021-0

[13] Gartzia, M., Pérez-Cabello, F., Bueno, C.G. and Alados, C.L. (2016) Physiognomic and Physiologic Changes in Mountain Grasslands in Response to Environmental and Anthropogenic Factors. Applied Geography, 66, 1-11. http://dx.doi.org/10.1016/j.apgeog.2015.11.007

[14] Liu, X.F., Zhu, X.F., Pan, Y.Z., Li, S.S., Ma, Y.Q. and Nie, J. (2016) Vegetation Dynamics in Qinling-Daba Mountains in Relation to Climate Factors between 2000 and 2014. Journal of Geographical Sciences, 26, 45-58. http://dx.doi.org/10.1007/s11442-016-1253-8

[15] Wessels, K.J., Prince, S.D., Malherbe, J., Small, J., Frost, P.E. and VanZyl, D. (2007) Can Human-Induced Land Degradation Be Distinguished from the Effects of Rainfall Variability? A Case Study in South Africa. Journal of Arid Environments, 68, 271-297. http://dx.doi.org/10.1016/j.jaridenv.2006.05.015

[16] Zhou, H., Rompaey, A.V. and Wang, J. (2009) Detecting the Impact of the Grain for Green Program on the Mean Annual Vegetation Cover in the Shaanxi Province, China Using SPOT-VGT NDVI Data. Land Use Policy, 26, 954-960. http://dx.doi.org/10.1016/j.landusepol.2008.11.006

[17] Wessels, K.J., Prince, S.D., Frost, P.E. and Van Zyl, D. (2004) Assessing the Effects of Human-Induced Land Degradation in the Former Homelands of Northern South Africa with a $1 \mathrm{~km}$ AVHRR NDVI Time-Series. Remote Sensing of Environment, 91, 47-67. http://dx.doi.org/10.1016/j.rse.2004.02.005

[18] Liu, S., Deng, L., Zhao, Q., DeGloria, S.D. and Dong, S. (2011) Effects of Road Network on Vegetation Pattern in Xishuangbanna, Yunnan Province, Southwest China. Transportation Research Part D: Transport and Environment, 16, 591-594. 
http://dx.doi.org/10.1016/j.trd.2011.08.004

[19] Sun, J.G., Wang, T. and Yan C.Z. (2012) The Relative Roles of Climate Change and Human Activities in Desertification Process. Journal of Desert Research, 32, 625-630. (In Chinese)

[20] Pekin, B.K. (2016) Anthropogenic and Topographic Correlates of Natural Vegetation Cover within Agricultural Landscape Mosaics in Turkey. Land Use Policy, 54, 313-320. http://dx.doi.org/10.1016/j.landusepol.2016.02.029

[21] Cheng, L.S., Wu, P.T. and Zhao X.N. (2011) Soil Mineralized Nutrients Changes and Soil Conservation Benefit Evaluation on Green Project Grain in Ecologically Fragile Areas in the South of Yulin City, Loess Plateau. African Journal of Biotechnology, 10, 2230-2237.

[22] Zhang, M.S. and Lu, N. (2013) Responses of Vegetation Ecology to the Climate Changes and Human Activities: A Case Study at Yulin Energy \& Chemical Industry Base. Geological Review, 59, 909-918. (In Chinese)

[23] Wang, T., Yu, D.X. and Yang, Q. (2014) Characteristics of Spatial-Temporal Change of Precipitation in Loess Plateau Area of Northern Shaanxi. Journal of Water Resources \& Water Engineering, 25, 24-29. (In Chinese)

[24] Xu, J.H. (2002) Mathematical Methods in Contemporary Geography. Higher Education Press, Beijing, 37-70. (In Chinese)

Submit or recommend next manuscript to SCIRP and we will provide best service for you:

Accepting pre-submission inquiries through Email, Facebook, LinkedIn, Twitter, etc.

A wide selection of journals (inclusive of 9 subjects, more than 200 journals)

Providing 24-hour high-quality service

User-friendly online submission system

Fair and swift peer-review system

Efficient typesetting and proofreading procedure

Display of the result of downloads and visits, as well as the number of cited articles

Maximum dissemination of your research work

Submit your manuscript at: http://papersubmission.scirp.org/

Or contact gep@scirp.org 